\title{
Discursos \\ Anticomunistas e \\ a Literatura Russa \\ na Era Vargas
}

Bruno Barreto Gomide*

RESUME: Este artigo apresenta as principais tipologias da literatura russa feitas pelos discursos anticomunistas no Brasil da primeira Era Vargas (19301945). Eles desqualificam a literatura russa produzida no período posterior a 1917 e concentram-se na do século dezenove, que é enquadrada em três chaves em relação ao comunismo (incompatibilidade radical, identidade total e contato problemático).
ABSTRACT: This article presents the main tipologies of Russian literature produced by anti-communist discourses in Brazil during the first Vargas Era (1930-1945). These discourses rule out Russian literature written in the post-1917 period and focus on Nineteenth-Century literature. Its relation to communism is defined in three ways (radical incompatibility, total identity and problematic contact).

Palavras-chaves : literatura russa, anticomunismo, Estado Novo Keywords: Russian literature, anti-communism, Estado Novo 
* Professor livre-docente de literatura e cultura russa na Universidade de São Paulo (bgomide@usp.br).Pesquisa realizada com apoio do CNPq. Este artigo é uma versão reduzida de um capítulo da tese de livre-docência defendida em junho de 2016 na USP (título: "Dostoiévski na Rua do Ouvidor: a literatura russa e o Estado Novo").

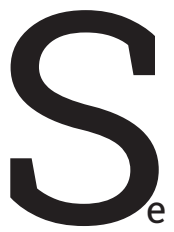

há um tema que surge quando se pensa na relação entre a literatura russa e a Era Vargas é o da atuação dos órgãos policiais e estatais, respaldada pelo anticomunismo de parcelas significativas da população brasileira. Vem aumentando a bibliografia sobre a apreensão de livros "vermelhos" e a censura a atividades comunistas ou definidas como tais na Era Vargas. ${ }^{1}$ É uma linha de pesquisa que ainda apresenta espaço para crescimento, em virtude da força que vêm adquirindo os estudos de história do mercado editorial. Ela tende a associar, com boa dose de razão, o significante "Rússia" a uma repressão que lhe era quase automática, efetuada por diversos agentes e instituições: delegados de polícia, informantes, vizinhos delatores, senhoras assustadas, intelectuais católicos e integralistas, párocos, políticos de tipo variado, órgãos de censura, jornalistas influentes - em suma, uma complexa rede social de vigilância nutrida simultaneamente por uma propaganda bem azeitada e por anseios articulados no âmago da sociedade brasileira.

A atribuição de um caráter subversivo aos textos russos, embora permeasse a cultura da época, não era um dado monolítico. Havia um intenso debate a atravessar toda a Era Vargas sobre como enquadrar a literatura russa no universo "vermelho". Em função do lugar decisivo que ela ocupara na vida intelectual do país, era uma discussão fundamental, travada com paixão e agressividade. Os escritores russos haviam adquirido uma autonomia simbólica que lhes permitia serem colocados

\footnotetext{
1 Ver por exemplo, Marisa Midori Deaecto e Jean-Yves Mollier (orgs), Edição e Revolução: leituras comunistas no Brasil e na França, 2013, e a série de pesquisas coordenada por Maria Luiza Tucci Carneiro a partir de arquivos do DEOPS: Maria Luiza Tucci Carneiro e A. G. Andreucci (Org.); V. Oliveira (Org.), Inventários DEOPS. Cultura Amordaçada. Intelectuais e Músicos sob a vigilância do DEOPS, 2002. Maria Luiza Tucci Carneiro e T. Wiazovski (Org.), Inventário DEOPS. Bolchevismo e Judaismo. A Comunidade sob o olhar do DEOPS, 2001.
} 
no mesmo patamar de relevância e urgência que os textos de Lênin e Trótski.

A questão primordial era saber qual a relação da literatura russa com o fenômeno comunista. As respostas eram muito variáveis. Dostoiévski e Tolstói eram, afinal, mentores intelectuais do bolchevismo? Ou, pelo contrário, situavam-se em seus antípodas, constituindo uma reserva antimaterialista e anticomunista que poderia inspirar a cultura brasileira? Ou, ainda, antecipavam o fenômeno revolucionário e descreviam suas bases intelectuais na sociedade russa do século dezenove, sem, todavia, poderem ser politicamente responsabilizados por ele? Essas perguntas se entrecruzaram em várias instâncias da vida cultural brasileira - jornais, projetos editoriais, livros didáticos, ensaios e, inclusive, no âmbito das práticas repressoras da vigilância policial.

Uma primeira diferenciação fundamental para se aferir a proximidade da ficção russa com o bolchevismo era feita entre a tradição literária do século dezenove e a literatura surgida depois da revolução. A noção hegemônica no discurso anticomunista era a de que havia um corte abruto entre as duas. Os fenômenos literários posteriores a 1917 seriam, nesse sentido, amplamente inferiores ao cabedal constituído pelos grandes prosadores do período pré-revolucionário. A nova cultura representaria um drástico rebaixamento de nível, e os escritores soviéticos, em sua enorme maioria, não passariam de simples funcionários do Estado produzindo mecanicamente algo que apenas se assemelhava à arte, mas na verdade era pura propaganda. ${ }^{2}$ Críticos importantes eram trazidos em apoio a essa ideia. "O comunismo matou a literatura russa", o título sonoro de uma reportagem sobre um ensaio do italiano Renato Poggioli, que já era reconhecido como um eslavista proeminente, resume a questão, ${ }^{3}$ continuada na segunda metade dos anos quarenta, quando os temas da arte dirigida e do realismo

\footnotetext{
2 Nicias Mourão, "Mortais e imortais", Correio paulistano, 31 maio 1940.

3 "O comunismo matou a literatura russa", Jornal do Brasil, 13 fev. 1938; "A decadência da literatura russa sob o comunismo", A Batalha, 24 fev. 1938. Nessa linha, o informe retirado de um jornal alemão: "O soviete matou a literatura russa”, Diário da manhã, 31 mar. 1931.
} 
socialista começaram efetivamente a ser discutidos no Brasil. Segundo esse raciocínio, os novos escritores russos eram todos tutelados pelo Estado. Apesar dos horrores do tsarismo, os do século dezenove haviam produzido arte genuína. ${ }^{4}$ No contexto pós-Estado Novo, fizeram-se paralelos entre a cooptação dos artistas no regime soviético e a dos intelectuais brasileiros durante a ditadura: lá como cá, os poetas haviam entoado "odes ao poder" e ressecado como artistas. ${ }^{5}$

A morte da literatura russa já fora anunciada logo após outubro de 1917, e contaminava até textos que não eram contrários à revolução em si. Havia um clima de apreensão sobre o que seria da literatura russa nas novas condições, tão brutais e indefinidas. Apesar de a Rússia ter se "libertado dos seus grilhões" e de certas manifestações culturais irem bem, como o teatro, os escritores estavam condenados ao silêncio, e o futuro da literatura era "imprevisível", dizia uma reportagem. ${ }^{6} \mathrm{Em}$ uma nota de otimismo parcial, as notícias que chegavam eram "apavorantes", mas o desenvolvimento da cultura musical, por outro lado, era "excelente".7

A discussão sobre os méritos e a herança da literatura soviética tinha certa monta na cultura brasileira. Mas o cerne da questão era a literatura do século dezenove. Sobre ela versava a disputa simbólica fundamental. Aquele era o patrimônio que tinha que ser avaliado. Ele continha autores essenciais para a formação literária de indivíduos particulares e da cultura nacional como um todo. Havia conhecimento e intimidade dos intelectuais brasileiros em relação a suas obras. Podemos dividir as reações a esse problema em três grupos, segundo os quais a literatura russa do século dezenove

1. não tinha nenhuma relação com o comunismo/bolchevismo. Vivos fossem, aqueles escritores chegariam

\footnotetext{
4 "Arte dirigida", Jornal do Brasil, 21 set. 1946; Joaquim Thomaz, "Registro literário", Jornal do Brasil, 21 set. 1949.

5 Mário Nunes, "Fatos e nomes", Jornal do Brasil, 28 maio. 1947.

6 "A Rússia vermelha - os dias amargos da literatura russa”, O Jornal, 15 out. 1919.

7 João Nunes, "Cultura musical na Rússia”, Diário carioca, 6 abr. 1930.
} 
inclusive a condená-lo. Associá-los era um ato de má-fé intelectual ou de doutrinação política.

2. era uma precursora do comunismo/bolchevismo. Nessa acepção, para o anticomunismo, ela tinha que ser responsabilizada e punida.

3. Mantinha relações complexas de proximidade e distância com o comunismo/bolchevismo, profetizando-o, descrevendo-o ou servindo parcialmente de base ideológica a muito do que ocorreu na Rússia revolucionária. Nesse caso, a relação do anticomunismo com ela será ambígua.

Elas começaram a ser estabelecidas imediatamente após a Revolução Russa e se difundiram em níveis variados, com predomínio da primeira. Passemos, então, a um panorama dessas três interpretações.

O postulado de uma separação drástica entre a literatura russa oitocentista e o comunismo foi muito comum entre os anos vinte e quarenta. Logo após 1917, o escritor mais convocado para esse fim foi Górki, que então mantinha uma relação turbulenta com os "maximalistas", nome dado então aos bolchevistas pela imprensa internacional, a partir de um curioso caso de má tradução do termo russo. Górki negava o seu pertencimento àquele partido e alegava "adorar o povo russo". ${ }^{8}$ Desenhava-se aqui uma contraposição entre bolchevismo e nacionalismo, qualidade atribuída amplamente aos russos, que se tornaria muito difundida. Em outros momentos evocava-se a sua atividade à frente do periódico Nóvaia Jizn (A vida nova) e seu papel de defensor do patrimônio cultural russo contra o desmantelamento promovido pelo novo regime. ${ }^{9} \mathrm{~A}$ sede de destruição e de barbárie cultural atribuída ao bolchevismo naquele momento lembrava muito os termos que, vinte anos depois, seriam pespegados ao nazismo. Alguns relatos utilizavam imagens fortes. Segundo um deles, Górki não se

\footnotetext{
8 "Gorki e os bolchevistas", Fon-fon, 31 jul. 1920.

9 Otto Prazeres, "O bolchevismo na prática”, Correio paulistano, 3 jan. 1920; Carlos Sá, "A obra pedagógica dos bolchevistas", O Jornal, 7 dez. 1920.
} 
distanciava do comunismo bolchevique apenas pela ausência de vínculo partidário e pela atuação em instituições culturais, mas em função das críticas severas lançadas por ele à chefia do partido, que, entre outras malfeitorias, ordenava tétricas experiências de vivissecção em seres humanos..$^{10}$ Do ponto de vista anticomunista, era uma situação ideal. As mazelas do novo regime eram desfiadas pela voz de um preclaro representante da literatura russa. Os títulos dos artigos deixavam claro: "Palavras de Gorki contra o bolchevismo", "Uma comédia de Gorki - a caricatura dos homens de governo na Rússia", ou ainda este, baseado em uma expectativa muito difundida durante o período de extrema indefinição da Guerra Civil, quando muitos supunham que o fim da tentativa bolchevique era provável: "Máximo Gorki afirma que o sistema dos soviets tem os seus dias contados na Rússia". ${ }^{11}$ Por vezes, a notícia caprichava nas tintas emotivas: "Maximo Gorki era sinceramente contra o comunismo!"12

A outro adversário encarniçado da política imperial, morto em data relativamente próxima para que sua voz possante ainda reverberasse, estava reservado um tratamento similar. Bolchevismo e Tolstói haviam se incompatibilizado, mesmo que o famoso escritor tivesse sido, dentre todos os russos do século anterior, "a bandeira das idéias que hoje ali são postas em realização", assegurava uma reportagem..$^{13} \mathrm{O}$ "Lenine club", de Moscou, tendo como promotora Nadiéjda Krúpskaia, viúva de Lênin, e Anatóli Lunatchárski como defensor, processara o escritor pela difusão de idéias burguesas, mas o júri decidira pela culpabilidade e pela destruição de obras como Ana Kariénina e Ressurreição, revertendo-se o papel, um bem pre-

\footnotetext{
10 "Máximo Gorki disse que a ambição dos chefes maximalistas os leva a ordenar experiências de vivissecção em seres humanos", Jornal do Brasil, 5 mar. 1920.

11 "Palavras de Gorki contra o bolchevismo", O Jornal, 5 mar. 1920; "Máximo Gorki afirma que o sistema dos soviets tem os seus dias contados na Rússia", Jornal do Brasil, 4 out. 1921.

12 Correio paulistano, 3 abr. 1938.

13 "O processo de Tolstoi", Jornal do Brasil, 7 ago. 1924. Sobre a incompatibilidade de Tolstói com o "caos russo", ver também: "O centenário de Tolstói”, "Música russa contemporânea", Jornal do Brasil, 29 ago. 1928; e Vinicius, "A Rússia bolchevista", Tribuna, 22 mar. 1930.
} 
cioso naqueles anos, para a publicação das obras de Lênin, Zinóviev e Bakúnin. Porém, até a reportagem parecia confusa diante de uma informação como essa. "Será que merece totalmente crédito essa informação tão singularmente estranha"? Era uma das muitas lendas ventiladas na época, quase todas centradas na imagem central da destruição dos livros, jogada de um lado para outro no período entreguerras.

A literatura russa era frequentemente classificada como idealista pelo vocabulário crítico da época. No contexto do debate sobre o bolchevismo, era justamente essa qualidade que a tornava perseguida pela nova realidade cruenta e materialista da Rússia soviética. ${ }^{14}$ Se o país eslavo estava no "fundo do abismo", como proclamava o artigo de uma escritora emigrada, restava pensar nas palavras de Dostoiévski apostas como uma epígrafe gigantesca: "A Rússia é forte e tudo pode suportar, e continuará sendo, sempre e apesar de tudo, a mesma Santa Rússia"..$^{15}$ Os abalos a que ela fora submetida foram colossais. O bolchevismo destruíra praticamente tudo que a cultura russa criara de modo brilhante: a música de Tchaikóvski, os balés russos, os coros ucranianos e a literatura de Dostoiévski, segundo o frei Pedro Sinzig. ${ }^{16}$ Outro cronista mencionava a incompatibilidade daquele último escritor com a "raça latina". Ele tinha em mente as restrições de extração francesa à literatura dostoievskiana feitas no final do século, para as quais a clareza e proporção clássicas supostamente inerentes àquela tradição colidiriam com o tumulto de formas proposto pelo russo. Mas isso era um erro, assevera. Não havia problema na aclimatação de Dostoiévski. A discordância real do espírito latino era com o bolchevismo ${ }^{17}$ Se o autor de Crime $e$ castigo vivesse, enfim, concluiria que o anticristo triunfara. ${ }^{18}$ Essa concepção de um Dostoiévski cultor do espírito, do ideal e da filosofia era muito difundida, em contraste mais ou me-

\footnotetext{
14 "Qual o caminho a seguir?", Jornal do Brasil, 23 out. 1927.

15 Ana Hanenko, "As tragédias da Rússia", Correio da manhã, 5 ago. 1921.

16 Frei Pedro Sinzig, "0 colosso britânico”, Jornal do Brasil, 25 dez. 1927.

17 Nemésio, "Destinos russos" e "Um grande ator", Correio paulistano, 31 jul. 1927.

18 Affonso Celso, "Humanidade desarraigada", Jornal do Brasil, 12 mar. 1935.
} 
nos explícito com o materialismo tosco atribuído ao bolchevismo ${ }^{19}$ Os demônios, romance do anticomunista Dostoiévski, já desmascarara Lênin, o "czar vermelho" ${ }^{20} \mathrm{E}$ era o idealismo daquele escritor e de Tolstói que o padre Helder Camara, naquele momento afinado com o integralismo, futuro arcebispo de Olinda e Recife e importante personagem do catolicismo brasileiro, contrapunha à doutrina comunista. ${ }^{21}$ No fim das contas, a Rússia ultrapassara todos os limites de brutalidade esperados de uma transição de regime, e o bolchevismo degenerara em "orgias", "espasmos" e "chacinas", transformando o país em um reduto de "feras", "loucos" e "assassinos", conforme o parecer de Jayme Cardoso. ${ }^{22}$

Nos momentos imediatamente anteriores e posteriores ao estabelecimento do Estado Novo, a questão da relação dos escritores russos com o comunismo se tornou ainda mais premente. Como se tratava de embasar ou de legitimar o novo regime, os textos ficam mais virulentos, e as comparações, mais ousadas. Há títulos de reportagens que não deixam dúvidas: "Se Tolstoi vivo fosse, Stalin mandaria encerrá-lo nas masmorras de Moscou". ${ }^{23} \mathrm{Em}$ "Nunca existiu no mundo tão feroz escravidão", um ex-diplomata soviético emigrado em Roma afirmava, impropriamente, que ao contrário do novo sistema soviético, o tsarismo jamais afrontara os "inimigos os mais encarniçados: Gogol, Tolstoi, Soltikow (sic; refere-se a Saltykóv-Schedrín), Gorki". ${ }^{24} \mathrm{~A}$ literatura russa não apenas era distante do comunismo, mas era, por extensão, afim aos fundamentos do que logo seria o Estado Novo, proclamava uma outra série de argumentos. Em uma palestra proferida para uma rádio de Belo Horizonte, em setembro de 1937, o político Hilário Freire

\footnotetext{
19 Inclusive em trechos e citações do próprio Dostoiévski, como: "0 exílio". Jornal do Brasil, 30 ago. 1936.

20 Francisco Lopes, "Comunismo”, Jornal do Brasil, 11 mar. 1936.

21 Padre Helder Camara, "Livros sobre o comunismo", Jornal do Brasil, 22 ago. 1937.

22 Jayme Cardoso, "A terra encantada das estepes”, Correio paulistano, 15 fev. 1930.

23 "Se Tolstoi vivo fosse, Stalin mandaria encerrá-lo nas masmorras de Moscou", A noite, 26 mar. 1937.

24 “Nunca existiu no mundo tão feroz escravidão", Correio da manhã, 20 mar. 1938.
} 
pregava a vinda de um estadista forte que fosse capaz de debelar a anarquia, combater as "ditaduras proletárias e burguesas" e organizar o eterno problema da vastidão ingovernável do Brasil - este último aspecto geográfico, uma agrura similar ao "fardo de Tolstói" em relação à Rússia. O ditador providencial veio dois meses depois, mas infelizmente na pessoa de Getúlio Vargas, e não na de José Américo de Almeida, que Freire apoiava. ${ }^{25}$

Houve outros expedientes para afastar os escritores russos do regime soviético. Um deles, muito comum, foi lançar mão de comentários anticomunistas feitos pelos familiares dos próprios escritores. Tolstói, com sua prole numerosa, foi o mais mencionado. Durante a Guerra Civil, um de seus filhos dizia "haver um abismo entre as ideias do seu pai e o despotismo selvagem dos extremistas russos" ${ }^{26} \mathrm{~A}$ apropriação feita do legado tolstoiano pelos bolchevistas era infundada, e a doutrina de Lênin era muito distante da do conde. ${ }^{27}$ Condenar o bolchevismo, dizia o mesmo filho, dez anos mais tarde, era ser fiel a Tolstói (Gandhi era um exemplo de bom seguidor) ${ }^{28}$ Mais enfáticas ainda, por tratar-se de um depoimento prestado diretamente a jornais brasileiros, e não apenas reproduzido de agências internacionais, soavam as palavras de Aleksandra Tolstaia, filha mais jovem do escritor, radicada nos Estados Unidos desde 1929 e autora de um best-seller sobre suas agruras entre os bolcheviques. Lá ela recebera para uma entrevista a jornalista brasileira estreante Sylvia de Queiroz Lima, que realizava uma temporada de estudos na Flórida. O resultado da conversa, segundo um jornal, foi enviado a nada menos que o Departamento de Imprensa e Propaganda, o fornecedor dos meios para a realização da entrevista, evidentemente interessado no troar póstumo da voz de Tolstói em combate com os bolcheviques. Após ouvir de sua entrevistadora um "relato so-

\footnotetext{
25 "Os governos fortes na democracia econômica", Correio paulistano, 1 set. 1937.

26 Jornal do Brasil, n. 56. Rio de Janeiro, 26 fev. 1921.

27 "O conde de Tolstoi e o bolchevismo", Correio da manhã, 26 fev. 1921.

28 "Fiel à filosofia paterna, um filho de Tolstói condenou o bolchevismo", A noite, 26 ago. 1931.
} 
bre a campanha do governo brasileiro contra o comunismo", a ilustre parente de Liév Tolstói teria aplaudido as iniciativas tomadas e sentenciado: "o governo brasileiro não deve poupar energias nessa luta (...) se vivo fosse, Leon Tolstoi escreveria um outro Eu não posso calar" ${ }^{29}$

Ainda mais impactantes eram os relatos dos tristes fins de alguns escritores em função da ação, real ou presumida, dos bolcheviques. Embora esse recurso tenha sido explorado, haveria muito mais elementos disponíveis, porém inaproveitados, nessa linha - o fuzilamento do poeta acmeísta Gumilióv em 1921, a vítima inaugural do novo regime nos meios artísticos, para citar apenas um exemplo trágico, mas praticamente desconhecido no exterior. O primeiro caso a ser acompanhado mais de perto foi o de Andréiev, cujos contos e novelas eram muito populares fora da Rússia. Ele morreu no exílio finlandês, na miséria, bradando contra a revolução. ${ }^{30} \mathrm{O}$ suicídio de Maiakóvski teve alguma repercussão no momento em que ocorreu, ${ }^{31}$ mas o discurso anticomunista naquela altura não pôde se apropriar dele em toda a sua extensão. A possibilidade de associar a sua morte às desilusões com os rumos da revolução pressuporiam um conhecimento maior da vida do poeta. Os embates envolvendo o fim de Maiakóvski só foram se desenhando à medida que a década transcorria. Três dias antes do golpe que instituiu o Estado Novo, Barbosa Lima Sobrinho, por intermédio de Writers in Uniform, livro de Max Eastman que ajudou a divulgar a idéia da burocratização dos artistas soviéticos, criticava a falsidade da idéia de que o trabalho intelectual seria livre na União Soviética. O jurista apontou a repressão feroz do estado a escritores como Pilniak e Zamiátin e o suicídio de Maiakóvski. ${ }^{32}$

\footnotetext{
29 "Um libelo contra o regime soviético - uma grande escritora russa, filha de Tolstói, dá ao Brasil um impressionante testemunho dos horrores praticados no seu país", Correio da manhã, 26 mar. 1937. A entrevista foi publicada com destaque também em outros jornais.

30 "O trágico fim de Leonidas Andreieff", O Jornal, 29 ago. 1920.

31 "Suicidou-se o poeta e dramaturgo soviético Vladimir Mayakovsky", O Jornal, 15 abr. 1930.

32 Barbosa Lima Sobrinho. "O barômetro cultural”, Jornal do Brasil, 7 nov. 1937.
} 
Quando o poeta realmente surgiu como objeto de discussão, no contexto do Estado Novo, foi apresentado como um troféu da cultura soviética, e não como sua presa.

Os expurgos decorrentes do terror stalinista de 1936-38 coincidiram com a instauração do Estado Novo. Eles seriam um prato cheio para o anticomunismo - os próprios russos matando os seus escritores - mas, no campo literário, ficaram subutilizados. Os grandes processos políticos foram fartamente aproveitados pela imprensa e pelos intelectuais. ${ }^{33}$ Contudo, mesmo esses só revelavam uma pequena fração da violência sofrida pela sociedade soviética. Os seus impactos na intelligentsia levaram muito tempo para ser conhecidos e assimilados pelo público não russo. A rigor, o conhecimento da extensão da repressão precisou de todo o período soviético e é uma ferida aberta no mundo contemporâneo. Na literatura, o exemplo usado com mais constância era o de Borís Pilniak, preso em outubro de 1937 e executado em abril de 1938. Informes davam conta apenas do seu desaparecimento. ${ }^{34}$ Corriam rumores sobre a prisão de Dmítri Sviatopólk-Mírski, ${ }^{35}$ o príncipe emigrado autor de ensaios críticos talentosos que, para surpresa geral, voltara para a União Soviética exatamente durante o primeiro plano quinquenal e pereceria sete anos depois em um gulag no extremo-oriente russo. Mas essas notícias eram tateantes e rarefeitas, dada a impossibilidade de obtenção de informações. As vítimas do jdanovismo no pós-guerra, como Zóschenko e Chostakóvitch, tiveram um acompanhamento mais minucioso. ${ }^{36}$

$\mathrm{Na}$ época sob exame, o acontecimento mais rumoroso foi a morte de Górki, em junho de 1936. Naquele momento predominou o pranto ao grande escritor, embora ressalvas ao seu pacto com o stalinismo tenham sido articuladas. Menos de

\footnotetext{
33 "Um mar de sangue para a cólera de Stalin!", A noite, 20 dez. 1937 (o texto fala de treze mil vítimas de execuções); Celso Vieira, "Bolchevo", $A$ noite, 6 nov. 1937.

34 J. S. Maciel Filho, "A sede dos deuses vermelhos", 0 imparcial, 21 dez. 1937.

35 "Continua na Rússia a obra de saneamento", Jornal do Brasil, 21 jul. 1937.

36 "Por esses caminhos do mundo - Rússia - ars gratia partis", Revista do Globo, 26 out. 1946.
} 
dois anos depois, contudo, precisamente em meio ao período em que o Estado Novo se instalava e o anticomunismo corria à brida solta, especulou-se que ele teria sido assassinado a mando de Stálin e de Iágoda, chefão do NKVD. Essa notícia foi amplamente divulgada pelos jornais brasileiros. ${ }^{37}$ Naquele contexto, era um argumento perfeito. Tratava-se do escritor mais querido pelas esquerdas, mais associado à cultura soviética. Se até dele haviam se livrado, ficava comprovado definitivamente $o$ antagonismo entre comunismo e a literatura russa.

A emigração de escritores russos para o ocidente, em decorrência da revolução, foi outro recurso usado com surpreendente moderação pelo discurso anticomunista. Nada mais natural para desmascarar a discordância entre o bolchevismo e os literatos do que ressaltar as gigantescas levas de artistas exilados que aportavam em Berlim, Praga ou Paris. Mas o tópico ficou restrito a comentários esporádicos. Segundo um deles, após a morte da literatura russa pelas mãos do soviete, aos escritores russos só restaria seguir para o estrangeiro. ${ }^{38} \mathrm{~A}$ parcimônia no uso dessa munição se deve, entre outros motivos, à pouca visibilidade e dispersão da maioria desses artistas emigrados em seus novos meios, dificultando a criação de blocos compactos e incisivos de informação. Ainda assim, vemos frequentemente assinalada a saída forçada de Górki, ou do "amigo de Górki", Dmitri Merejkóvski, o "genial escritor que os sovietes expulsaram". ${ }^{39}$ Este último foi um dos raros a ter o termo "exílio", uma referência concreta à experiência da emigração, atrelado ao nome. ${ }^{40}$

\footnotetext{
37 "Assassinado Maximo Gorki", A noite, 8 mar. 1938; "O fim de Gorki", Correio da manhã, 29 maio 1938; "Stalin e a morte de Gorki", $A$ Batalha, 6 mar. 1938; "Máximo Gorki e seu filho foram assassinados por ordem de Stalin", A Batalha, 10 mar. 1938; "Stalin mandou que se desembaraçassem de Gorki?", Correio do Paraná, 16 jun. 1938; "A única pessoa interessada em fazer desaparecer Maximo Gorki era Staline", Jornal do Brasil, 6 mar. 1938; "A tragédia de Gorki", Diário carioca, 11 mar. 1938; "Maximo Gorki e seu filho foram assassinados", Gazeta de notícias, 9 mar. 1938; "Não foi natural a morte de Gorki", Diário de notícias, 9 mar. 1938; "As edições de livros de Gorki", Jornal do Brasil, 10 maio 1938.

38 "O soviet matou a literatura russa", Diário de notícias, 17 abr. 1931.

39 "O soviet matou a literatura russa", Diário carioca, 11 abr. 1931; "0 amigo de Gorki - Merejkovsky, o genial escritor que os soviets expulsaram", Diário da noite, 23 jan. 1936.

40 "Um escritor russo no exílio", O Jornal, 20 mar. 1921.
} 
Escritores ocidentais desencantados com a União Soviética também serviam para indicar a oposição entre a grande literatura russa e o bolchevismo. Os artefatos mais respeitáveis eram os relatos de viagem de André Gide, convidado pelo governo soviético a visitar o país entre junho e setembro de 1936. $\mathrm{Na}$ área da literatura russa, Gide adquirira reputação em virtude de seus ensaios sobre Dostoiévski, muito apreciados no Brasil. Esse mesmo estudioso da ficção russa e, até bem pouco tempo, companheiro de viagem, agora tecia sérias restrições ao sistema soviético. Em seu Retour de l'URSS, muitas dessas restrições são pontuadas com alusões a escritores russos. A crítica de Gide encontrou terreno fértil no Brasil,41 às vésperas do Estado Novo, havia quem considerasse necessária a sua difusão em grande escala. ${ }^{42}$

A literatura russa tinha uma importância vital para um dos grupos de intelectuais adversários figadais das idéias comunistas. Os católicos leigos e o grupo apenso dos "modernistas espiritualistas" foram atores políticos e culturais de grande relevo na Era Vargas. Sua tendência foi a de valorizar radicalmente os textos da ficção e do pensamento russo do século dezenove, erigindo-os como uma muralha diante da desumanização do homem atribuída ao comunismo soviético. Nas obras de Jackson de Figueiredo, Alceu Amoroso Lima, Augusto Frederico Schmidt, Tasso da Silveira e outros, a literatura russa era uma interlocutora primordial. Ao contrário do bolchevismo, ela nada tinha de ameaçadora. Pelo contrário, representava um caminho de salvação para a cultura brasileira e universal. Em constância e extensão, eles produziram um corpus ensaístico que, apesar de empanado pelas lides políticas da hora, de modo simétrico inverso ao que a leitura comunista da literatura russa estava fazendo, ajudou a trazer para a crítica literária brasileira aspectos relevantes dos textos russos que não haviam estado na pauta até então, sobretudo a visada de

\footnotetext{
41 "O depoimento de Gide”, Correio da manhã, 9 maio 1937; "Depois que André Gide voltou da URSS", Correio da manhã, 17 jan. 1937; A. Shaw, "André Gide e Fernando Celine vomitam sua fé comunista", Correio da manhã, 12 fev. 1937.

42 Carta de Nelson Teixeira de 24 ago. 1937 a Nestor Duarte (CPDOC).
} 
matriz simbolista, mediada por determinados setores da emigração russa. ${ }^{43}$

O segundo conjunto de atitudes sobre a responsabilidade da literatura russa diante do bolchevismo seguia uma diretriz oposta. Ela apagava as distinções entre Tolstói e Lênin tão cuidadosamente elaboradas pela interpretação concorrente. Os escritores russos passavam a ser, então, teóricos do comunismo. Eram parte do mesmo material, e sua ficção, mais ideologia do que arte, nada tinha de idealismo redentor. $\mathrm{Na}$ descrição a seguir, aterei-me a posições de extração anticomunista, visto que as leituras à esquerda quase sempre davam por certo, evidentemente sob um ângulo positivo, que a grande tradição literária russa era uma parceira do fenômeno revolucionário (variando os níveis dessa cooperação). Um exemplo é a entrevista do escritor paraibano Carlos Dias Fernandes, que elogiava Lênin e afirmava que este fora movido à ação pela leitura de Tolstói, Górki e Dostoiévski. ${ }^{44}$ Do ponto de vista das direitas, essa lógica insuflava e fornecia legitimidade a ações violentas contra os indivíduos e livros associados à Rússia.

Formulações parelhas pululavam: o bolchevismo seria resultado direto das idéias de Lênin, Trótski e Górki. ${ }^{45}$ Este escritor e mais Tolstói sacudiram o país com suas "doutrinas subversivas" ${ }^{46} \mathrm{~A}$ revolução sem dúvida emanara dos romances de Dostoiévski. ${ }^{47}$ Górki era um assecla do comunismo, por negar a conexão entre este e o judaísmo. ${ }^{48}$ Pela oposição frontal que haviam feito aos tsares, todos os escritores russos eram comparsas de um tipo de anarquia não-ocidental e, logo, parentes espirituais do bolchevismo. ${ }^{49}$ Os festejos do décimo aniversá-

\footnotetext{
43 Ver o cap. "O terceiro elemento" em Bruno Gomide, Da estepe à caatinga: o romance russo no Brasil (1887-1936). São Paulo, Edusp, 2011.

44 Roberto Lyra e Pedro Motta Lima, "A questão social no Brasil”, A manhã, 23 jan. 1926.

45 “O maximalismo alastra-se”, Jornal do Brasil, 11 jan. 1919.

46 "Seção religiosa. Lenine e o Papa", Jornal do Brasil, 28 jul. 1920; e também: "As cartas de Tolstoi", Jornal do Brasil, 4 fev. 1926.

47 "A glória de Jaurès", Jornal do Brasil, 14 set. 1924.

48 “Ora, o Sr. Gorki...", O Jornal, 29 abr. 1924.

49 “Na Rússia dos soviets”, Diário da manhã, 1 dez. 1925.
} 
rio da revolução tiveram representações de cenas de Tolstói, Dostoiévski e Górki, "propagandistas do credo vermelho".50

Encarar Lênin como uma ramificação da literatura russa era uma cartada decisiva do discurso anticomunista. No entanto, a comparação com o próprio pai fundador da doutrina também era um artifício possante. Do ponto de vista do Centro D, Vital, Marx, Tchernichévski, Górki, Tolstói e Lênin eram nomes afins. ${ }^{51}$ Para a escritora Leontina Licínio Cardoso, a Rússia era o país de "Tolstoi e Carl Marx", aliados na desgraceira bolchevique. ${ }^{52}$ Seu irmão, Vicente, havia concordado com a idéia de uma tragédia abatida sobre a Rússia, mas escrevera bastante na década de vinte para tentar matizá-la: mais importante do que o comunismo era o fato de a Rússia ter produzido grandes escritores, em especial um, Dostoiévski, que transcendera a azáfama da política e conseguira resolver o impasse da representação literária da nacionalidade.

Ao Górki salvaguardado pelo anticomunismo correspondia o escritor interpelado como unha e carne da revolução. A primeira linha extraía argumentos das críticas gorkianas aos primeiros tempos bolcheviques e deleitava-se com a sua morte mal-explicada. A segunda retomava o seu passado revolucionário e encontrava material copioso, à medida que a década de trinta avançava, na sólida parceria estabelecida com as diretrizes culturais do Estado stalinista. Tratava-se, então, de um apóstolo do comunismo, uma figura completamente identificada com o regime..$^{53}$ Parte da imprensa brasileira tentou transformá-lo em inimigo da revolução, inutilmente: ele era sua essência, assegura um jornalista. ${ }^{54} \mathrm{Em}$ debates da Câmara dos Deputados, Attila Soares atacava Anisio Teixeira. Ele estaria bolchevizando o ensino distribuindo em escolas livros

\footnotetext{
${ }_{50}$ "A comemoração do $10^{\circ}$ aniversário do regimen soviético na Rússia", Jornal do Brasil, 8 nov. 1927.

51 Francisco de Laura, "Um manifesto fracasso", O Jornal, 14 jul. 1935.

52 Leontina Licinio Cardoso, "Impressões de um livro", A Batalha, 13 abr. 1932.

53 "O jubileu de Gorki festejado pela Rússia", Correio da manhã, 3 ago. 1928; Bruno Pereira. "Uma solução brasileira", Jornal do Brasil, 24 fev. 1932.

54 Y. "Cartas cariocas", Correio paulistano, 26 jun. 1936.
} 
de Gorki, Barbusse e outros autores comunistas. ${ }^{55}$ Era com desgosto que uma revista católica universitária registrava, em meio à Guerra Civil, que o Convento de Jesus mudara de nome para Casa Máximo Gorki. ${ }^{56}$ Segundo um artigo condenatório do "extremismo" brasileiro, Górki, uma figura do mesmo jaez, não passava de um hipócrita por ter reclamado quando foi expulso dos Estados Unidos (é um exagero do jornalista, já que o russo foi "apenas" expulso do hotel novaiorquino onde estava hospedado), e agora defendia, na União Soviética, a mão de ferro do Estado. ${ }^{57}$ Para a Gazeta de notícias, uma boa mostra do caráter bolchevizante da revista Diretrizes era a propaganda vermelha que ela fazia usando citações de Górki. ${ }^{58} \mathrm{Em}$ suma, ele era um apologista das atrocidades de Stálin ${ }^{59}$, um bolchevista puro ${ }^{60}$ e um teórico da "destruição da personalidade", na linha de Lênin e Marx. Gente mal-intencionada quis empurrar o seu pensamento coletivista aos brasileiros ${ }^{61} \mathrm{O}$ fato de posar lado a lado com Stálin em fotografias colossais, sorridente e aparentemente confortável, fornecia mais munição para essa argumentação. ${ }^{62}$

Com as direitas ainda mais eriçadas depois do levante de 35 , o argumento atingiu a incandescência, especialmente quando se tratava da relação entre comunismo, textos russos, bibliotecas e escolas. A ansiedade sobre os efeitos maléficos na formação da juventude vertebrava o discurso anticomunista. Uma diligência da polícia de Buenos Aires descobrira uma escola "mantida por Moscou, exclusivamente para inocular no espírito dos meninos argentinos as ideias comunistas". Ensinava-se o desrespeito a tudo o que era sagrado, distribuía-se

\footnotetext{
55 "Na câmara municipal”, O imparcial, 13 ago. 1935.

56 L. A. B, "Fatos e comentários", Vida: revista universitária, ago. 1936.

57 H. C., "Como eles pensam e como eles agem", Jornal do Brasil, 26 out. 1938.

58 "Alerta com os comunistas!", Gazeta de notícias, 25 nov. 1941.

59 H. C. "A fraqueza de um regime de opressão", Jornal do Brasil, 15 fev. 1940.

60 Carlos Maul, “O Brasil alegre e confiado...", Correio da manhã, 17 dez. 1936.

61 J. S. Maciel Filho, "Davi e Golias”, O imparcial, 23 jan. 1940.

62 Richard Halliburton, "Uma visita à Rússia soviética”, Diário de notícias, 16 jul. 1937.
} 
folhetos de propaganda vermelha, imagens de Lênin e Stálin. O lado prático vinha nas aulas de química, em que as crianças, precoces revolucionários, aprendiam a fabricar pólvora e outros explosivos, além de manejar armas de fogo. O leitor já terá advinhado quais eram os livros-base usados nessa peculiar instituição carbonária infanto-juvenil:

Formavam-se pequenos monstros para serem os agitadores e os empresários de subversões no futuro. Os livros adotados nessa escola eram exatamente de autores russos: Dostoiewsky, Máximo Górki, Andreiew, Peretz e outros. ${ }^{63}$

Um acontecimento momentoso no primeiro semestre de 1936 teve a literatura russa no centro das discussões, apontada como peça de condenação inequívoca. Respaldado pela nova Lei de Segurança Nacional, a "Lei Monstro", ele ocorreu na esteira da violenta repressão ao levante comunista de novembro do ano anterior. O deputado João Mangabeira tentou impetrar pedidos de habeas-corpus para os prisioneiros recentes e denunciar as arbitrariedades cometidas pelo governo, mas foi ele mesmo preso, em março, juntamente com três outros deputados (Abguar Bastos, Domingos Velascos e Otávio Silveira, e mais o senador Abel Chermont, logo solto). Nos três meses seguintes, enquanto Mangabeira acusava, no cárcere, a polícia e Getúlio Vargas, a Câmara dos Deputados deliberava sobre o cabimento de um processo judicial dos parlamentares detidos. O parecer final, favorável à abertura do processo-crime e aprovado por 190 votos contra 59, coube ao deputado Alberto Álvares. O texto foi amplamente divulgado pelos principais jornais. Ele negava a possibilidade de aplicação prática do bolchevismo em um contexto como o brasileiro, ao qualificá-lo como uma "psicose racial" específica do povo russo e suas aspirações messiânicas. Quem quisesse estudá-lo em sua especificidade, devia recorrer a textos de Dostoiévski e Tolstói, que representavam respectivamente "a santidade na tragédia" e o "misticismo da renúncia". A este último cabia a responsabilidade maior: "Os psicanalistas do bolchevismo consideram Tolstói o seu maior, senão o seu único criador, através de mais

63 "Escolas de comunismo", Correio da manhã, 18 out. 1936. 
de meio século de exteriorização de seu fatalismo e messianismo". Obras como a Sonata a Kreutzer serviam de apoio a essa caracterização de Tolstói que, acrescida de uma batelada de dados tenebrosos sobre a história do comunismo, embasavam a denúncia ao caráter dissolvente e pecaminoso da Aliança Nacional Libertadora, da ação dos comunistas no Brasil e, consequentemente, ajudavam a instaurar o processo contra os deputados. ${ }^{64} \mathrm{O}$ jornal $A$ Federação, de grande circulação no Rio Grande do Sul, e que não era um jornal das esquerdas, saiu em corajosa defesa dos parlamentares presos e de Tolstói: Alberto Álvares, dizia a reportagem, chamara de comunista gente que ia de Pedro, o Grande, ao "genial" Dostoiévski, e parecia lamentar que Tolstói "não [fosse] vivo e não [fosse] brasileiro para mandar processá-lo também pelo crime de comunismo", mandando-o "preso e incomunicável à ordem do capitão Filinto Müller".65

A tendência dos intelectuais católicos leigos era não apenas separar o comunismo e a ficção russa, mas até propor esta última como uma alternativa ao primeiro. No entanto, os presbíteros - os padres, bispos e demais membros da hierarquia eclesiástica que foram articuladores capitais do discurso anticomunista - em geral tinham uma relação bem menos entusiasmada com a literatura russa, que consideravam prima próxima do comunismo, quando não sua irmã gêmea. $O$ cristianismo de Tolstói, por exemplo, era reprovado por ser contra a livre-propriedade e por lhe faltar a hierarquia católica. ${ }^{66}$

Alguns sacerdotes vararam décadas de anticomunismo incomodados com a literatura russa e suas perigosas filiações comunistas. O padre Assis Memória começou a publicar artigos violentos sobre o tema logo depois da Revolução Russa e se

\footnotetext{
64 "A licença para o processo dos parlamentares presos - o importante parecer do deputado Alberto Álvares", Correio da manhã, 5 jul. 1936. Houve republicações do parecer de Alberto Álvares, avalizado pelas colunas jurídicas (muitas vezes sem o nome do autor ou referência explítica ao caso que lhe inspirou) como um bom texto sobre as origens intelectuais e literárias do comunismo. Por exemplo, em: "0 comunismo não merece sequer ser um assunto para discussão e debate", Correio da manhã, 4 set. 1936.

65 “O Sr. Alberto Alvares e Tolstoi”, A Federação, 30 jun. 1936.

66 A. C., "A religiosidade russa”, Jornal do Brasil, 11 abr. 1921.
} 
manteve incansável até a nova ilegalidade do PCB, no governo Dutra. Não apenas traçava a origem literária do bolchevismo, como também clamava por medidas práticas de censura aos livros de ficção. Ele abriu os trabalhos denunciando os acontecimentos revolucionários de 1917, preparados pelas doutrinas de Tolstói e Górki. ${ }^{67}$ Acusou o militante anarquista José Oiticica como discípulo dos mesmos escritores ${ }^{68}$ Centrou suas baterias na ebulição russa da primeira febre, afirmando que os "evangelistas sociais" do século dezenove eram precursores do maximalismo. Era necessário proibir toda a literatura russa, pois tratava-se de uma "droga igual à cocaína". Para seu desespero, vira no Norte do Brasil ampla divulgação dela ${ }^{69}$ - pode-se pensar em Assis Memória esbarrando em Valdemar Cavalcanti em alguma livraria de Maceió ou Fortaleza, folheando, com reações muito diferentes, exemplares da Unitas ou da coleção de Selzoff. Diante do avanço da literatura soviética e da ameaça comunista, o sacerdote maneirou as suas posições sobre os textos oitocentistas. Ainda eram perigosos, mas tinham algumas qualidades estéticas e humanas, que faltavam inteiramente a Prestes, Maurício de Medeiros, Barbusse e todos os novos escritores soviéticos. Estes não passariam de "Tolstóis de subúrbio", "Dostoievskis de fancaria", "Maximos Gorkis de roça".$^{70}$ Esta será a sua opinião ao longo dos anos seguintes: a literatura russa é um foco irradiador de revolução e extremismo, jamais o depositório de ideal que parcela do discurso anticomunista advogava, e, portanto tem que ser monitorada e, de preferência, censurada. Porém, autores como Dostoiévski e Tolstói possuíam ao menos talento e gosto literário. ${ }^{71}$

Empenho do padre Assis Memória à parte, essa segunda linha é, em volume, menos expressiva do que a anterior. A maior parte do discurso anticomunista seguia estabelecendo uma distinção hierárquica entre literatura russa do século de-

\footnotetext{
67 Padre Assis Memória, "Rússia e Roma”, Jornal do Brasil, 4 set. 1921.

68 Assis Memória, "O Ruhr e o carvão", Careta, 17 nov. 1923.

69 Assis Memória, “Literatura russa”, Jornal do Brasil, 10 mar. 1932.

70 Assis Memória, "Literatura soviética”, Jornal do Brasil, 8 jan. 1936.

71 Assis Memória, "Literatura subversiva”, Jornal do Brasil, 19 out. 1937.
} 
zenove e o bolchevismo. No entanto, ela era estridente, tocava em pontos sensíveis, e ajudava a alimentar o clima de caça às bruxas. Eram duas posições extremas dentro do anticomunismo, afagando e hostilizando a literatura russa, incluindo-a e retirando-a do índex. Entretanto, havia uma terceira, importante, que permanecia em uma zona pardacenta.

Um setor dos discursos anticomunistas preferiu situar a literatura russa do século dezenove em um território mais reticente. Dostoiévski e Tolstói podiam, assim, profetizar ou até denunciar o comunismo soviético, ainda que mantivessem pontos de contato, potencialmente perigosos, com o magma tipicamente russo que o teria gerado. Ou podiam partilhar do mesmo espírito de revolta bolchevique contra os desmandos e injustiças do tsarismo, muito embora, se estivessem vivos e escrevendo durante o novo regime instaurado em 1917, talvez criticassem os seus exageros. Ou ainda meramente retratar tudo aquilo de um ponto de vista mais distanciado.

Qualquer leitor de Górki e Turguêniev, dizia o poeta Hermes Fontes, saberia que na Rússia ia acontecer uma revolução. ${ }^{72}$ Estava tudo lá prenunciado nos romances. Bastos Tigre concordava com ele, acrescentando-lhes o nome de Tolstói. ${ }^{73}$ Para certo "Antonius", a literatura russa não chegava a explicar inteiramente a revolução, embora fosse a única documentação sobre o país disponível a leitores ocidentais. Parecia-lhe que toda a realidade revolucionária era "realização e adaptação" de tal literatura. ${ }^{74} \mathrm{Um}$ publicista italiano asseverava ser grande a influência dos escritores russos no maximalismo. ${ }^{75} \mathrm{Compa}-$ rava-se as idéias de Trótski ou as de Marx com as de Tolstói e Górki, definidos também como "ideólogos". ${ }^{76}$

\footnotetext{
72 Hermes Fontes, "Renovações", Correio paulistano, 4 abr. 1917.

73 Bastos Tigre, "Cartas a um gatuno", Correio da manhã, 15 abr. 1920.

74 Antonius, "A Rússia", Fon-fon, 16 jun. 1917.

75 "A psicologia do maximalismo", O Jornal, 17 out. 1919.

76 Bueno Monteiro, "A marcha das ideias", Correio paulistano, 18 jul. 1919; e, para a "ideologia" dos escritores, "0 grande crime da Rússia”, Jornal do Brasil, 26 ago. 1919.
} 
Esses textos tinham um tom que não era nem de recusa veemente do comunismo, nem de entusiasmo pela Rússia soviética. Eles tentavam mapear e esquadrinhar o terreno com certa suspeita. Nessa linha, prevalece a reticência e o ceticismo. Alguns deles eram, inclusive, produzidos por autores que tinham simpatias por movimentos sociais, sem necessariamente pactuar com a visão de mundo comunista. Por isso, é com ressalvas que se pode alocar alguns deles na categoria do anticomunismo, e certamente não no sentido mais visceral exposto na maior parte deste capítulo.

Dostoiévski era visto como um antecessor espiritual do bolchevismo, doutrina que estaria na psicologia da nação russa. Porém, suas profecias somente estavam se cumprindo no que dizia respeito ao caos - infelizmente, não quanto à redenção, como lamenta um artigo. ${ }^{77}$ Cabe observar que havia uma linha muito clara, em certos textos, sobre o valor atribuído ao "caos" russo. Na literatura, a turbulência e a imprevisibilidade eram parte do charme; na política e na vida social, as mesmas tendências davam a fundamentação problemática do bolchevismo. ${ }^{78} \mathrm{~A}$ Rússia descrita por Dostoiévski era de instabilidade tremenda. Antes, um "Império governado por uma mulher histérica e por um monge libertino", hoje, uma "ditadura cruel". Por isso, o Brasil não deveria reconhecer o novo governo soviético. ${ }^{79}$ Para todos os efeitos, a "Rússia imensa" de Dostoiévski e Górki continuava a existir sob o bolchevismo ${ }^{80} \mathrm{E}$ ninguém duvidava que aqueles escritores, "sem premeditar", haviam produzido "obra de grande teor revolucionário" ${ }^{81}$ Ronald de Carvalho, perto do fim de sua curta vida, tateava: o futuro da Rússia era imprevisível, mas não se devia necessariamente prever o pior, afinal a Rússia já havia dado Dostoiévski, Tolstói

\footnotetext{
77 Mello Leitão, "Dostoievsky e a revolução russa”, O imparcial, 10 jun. 1922.

78 Abel Juruá, "Páginas soltas", Ilustração Brasileira, jul. 1926.

79 Dermeval Lessa, "Deve o governo do Brasil reconhecer o governo bolchevista russo?", Gazeta de notícias, 21 set. 1926.

80 "A Rússia também é original", Correio paulistano, 23 nov. 1929.

81 Aderbal Jurema, "0 anjo" e Jorge de Lima”, Diário carioca, 15 jul. 1934.
} 
e Górki, "homens de qualidade". ${ }^{82}$ Para Benjamin Lima, tudo que se passava na URSS podia ter sido escrito por Dostoiévski, já que ele estava tão conectado à alma do povo. ${ }^{83}$

Candido Motta Filho hesitava na avaliação daquele material ficcional russo. Fazia pender a balança para uma crítica mais enfática da Revolução. Advogado, jornalista e político, um polígrafo do modernismo de 22, escreveu sobre o teor do nacionalismo dos escritores russos, questão atroz que compartilhava com seus colegas de verde-amarelismo, Cassiano Ricardo e Menotti del Picchia. Com o primeiro teve em comum, durante o Estado Novo, a direção do Departamento Estadual de Imprensa e Propaganda. No seu entender, somente em um país de nacionalidade fraca e semibárbaro como a Rússia a revolução pudera vingar. Górki descrevera bem o tipo humano que lastreava aquele patriotismo fraco, o mujique dispersivo e desfibrado. A alusão de Motta Filho ao estilo "ondulante e vagaroso" gorkiano implicitamente propõe que o escritor e os camponeses partilhavam da mesma substância amorfa. ${ }^{84}$ Não havia dúvidas sobre o combate renhido que deveria ser dado no Brasil à "praga" comunista, de uma inspiração asiática que perpassava todos os escritores russos - Merejkóvski, Bakúnin, Lênin e Tolstói, chegando inclusive a Dostoiévski, o "escritor mais adorado na Rússia, e nas camadas contaminadas pelos ideais comunistas, (...) esse grande apóstolo da orientalização do mundo" ${ }^{85}$ Impossível resolver a questão em uma síntese fácil. Os russos eram ao mesmo tempo grandes nacionalistas e mentores do bolchevismo, santos e demônios (um de seus artigos intitula-se "A humanidade santificada de Leão de Tolstói), etnicamente eslavos, mas preocupados com os problemas universais da humanidade, gigantes da literatura moderna ${ }^{86}$

\footnotetext{
82 "As quatro Europas e o Brasil", O Jornal, 14 dez. 1934.

83 Benjamin Lima, "Páginas de Dostoievski não escritas por ele", Correio paulistano, 26 set. 1934.

84 Motta Filho, "O estudo dos valores nacionais", Correio paulistano, 5 jul. 1926.

85 Motta Filho, "A repressão social ao comunismo", Correio paulistano, 27 jul. 1927.

86 Motta Filho, "As leituras da semana", Correio paulistano, 25 jul. 1929; Motta Filho, "As leituras da semana", Correio paulistano, 18 set. 1929.
} 
Dostoiévski, em especial, apresenta para Motta Filho a interrogação mais excruciante: como equacionar a sua inexcedível união de humanidade e região com aquele apostolado orientalizante e perturbador?

O mesmo tipo de ansiedade foi manifestado por Gustavo Barroso no decorrer de décadas. O misto de fascínio e de horror que ele tinha por uma literatura russa transbordante de visão trágica do mundo e de política violenta talvez seja o melhor exemplo brasileiro de certo tipo de apropriação que o pensamento de direita do entreguerras fez dos textos russos, sobretudo os de Dostoiévski. Eles traziam a revolução ou não? Se sim, que tipo de revolução era essa? Política ou interior, da "alma"? É algo que parece atormentar Barroso, tradutor e comentador, nunca é demais lembrar, dos Protocolos dos sábios de Sião, lançado pela Civilização Brasileira em 1936, um texto-chave do antissemitismo forjado precisamente naquela Rússia profunda e turbulenta que, ao final do século dezenove, sincretizava mística e revolução como em nenhum outro período de sua história. A Barroso não faltou sequer a etapa socialista da juventude, na sociedade literária do clube cearense "Máximo Górki". Em 1923, aos trinta e quatro anos, recém-eleito para a Academia Brasileira de Letras, Barroso iniciou a publicação de uma "empolgante novela de costumes da misteriosa Rússia". Era a sua contribuição para a não desprezível tradição brasileira de narrativas pseudo-russas, fornidas com o habitual repertório de tróicas, cossacos, mulheres fatais, nomes russos mal-ajambrados e muita neve. A certa altura, um personagem faz uma pergunta que cabe imaginar na cabeça de Barroso sobre aquela empreitada literária: "Que lucro você tira disso?, perguntar-me-ia esse pobre conde Ignatief. Sentir que sou diferente dos outros e capaz de fazer um romance de aventuras como Gogol não imaginaria..." ${ }^{87}$ É um folhetim de terceira categoria, motivado pelo desejo de criar um quadro de uma Rússia colorida, vital, sedutora e, por isso mesmo, perigosa.

${ }_{87}$ Gustavo Barroso, "Antes do bolchevismo" (novela), V , 15 set. 1923. 
Alguns anos depois, já militante da Ação Integralista Brasileira, Barroso publicou na revista Fon Fon, da qual foi diretor durante muitos anos, um artigo em que simpatizava com a intelligentsia russa, a elite intelectual perseguida antes pelo regime tsarista e agora pelos novos detentores do poder. Tiranias e revoluções, segundo ele, eram mais ou menos a mesma coisa, variando apenas a relação do povo com elas. Porém, esses luminares russos - Radíschev, Novikov, Tchaadáiev, Belínski, Griboiédov, Herzen, Púchkin, Turguêniev, Dostoiévski, Korolienko, Tchernychévski, Solovióv, citados com grafias estropiadas - não eram inocentes. Todos haviam ajudado, "direta ou indiretamente", a desenvolver o "comunismo vitorioso" que agora os acossava de maneira ainda mais dura do que o sistema anterior ${ }^{88}$ Aqui, novamente, Barroso parece indeciso diante da admiração pelo talento e pelo protagonismo desses artistas-ideólogos e do temor pelo resultado concreto de suas idéias.

Vários escritores de esquerda interromperam seus projetos russófilos com a chegada do Estado Novo, só os retomando no declínio da ditadura. Gustavo Barroso é uma variante à direita do mesmo fenômeno. Ele apoiou o golpe de novembro de 1937, mas foi preso no ano seguinte, na sequência do levante integralista, e restringiu a sua atividade pública e jornalística. Prova, contudo, de que o tema russo continuava a inquietá-lo, é uma série de três longos artigos sobre "Dostoiévski e o bolchevismo" publicados em fins dos anos quarenta, quando se tornava premente, mais uma vez, reavaliar a relação do anticomunismo com a literatura russa. São textos muito detalhados, nos quais o gênio literário e filosófico do escritor é exposto na mesma medida em que se reconhece que ele também podia ser "puro bolchevismo" ou "parceiro" do apocalipse..$^{89} \mathrm{Não}$ fica

\footnotetext{
88 Gustavo Barroso, “Gente perigosa”, Fon Fon, 29 jul. 1933.

89 Gustavo Barro, "Dostoievski e o bolchevismo I - a negação do Cristo", A manhã, 21 jun. 1949; Gustavo Barroso, "Dostoievski e o bolchevismo II - a apresentação do Diabo", $A$ manhã, 28 jun. 1949; Gustavo Barroso, "Dostoievski e o bolchevismo III - o apocalipse da loucura", A manhã, 5 jul. 1949.
} 
nítido se Barroso é atraído por Dostoiévski apesar do bolchevismo ou justamente por causa dele. ${ }^{90}$

Nesse quesito de profeta-parceiro da turbulência política, havia consenso de que um lugar de destaque estava reservado para Dostoiévski. Os seus romances haviam sido o "prólogo da tragédia", ${ }^{11}$ e os tchekistas eram emulações de seus personagens. ${ }^{92}$ Entretanto, um livro em particular costumava ser evocado quando se tratava de avaliar o papel da ficção russa na profetização dos acontecimentos revolucionários. Os demônios e sua legião polifônica foram muito citados a partir de 1936, atrelados aos processos de Moscou, quando a revolução devorava os seus filhos. Discutir os sentidos da psique revolucionária era prato cheio para o anticomunismo. ${ }^{93}$

Uma relação prática com os perigos da representação literária russa pode ser encontrada em outro setor cultural relevante. Desde o fim do século dezenove, a literatura russa desfrutara de enorme prestígio em instituições jurídicas e penais brasileiras, fazendo parte da formação dos quadros - médicos criminalistas, advogados, juristas, delegados - que iriam julgar o destino das pessoas e livros vermelhos. ${ }^{94}$ Quando se chega à Era Vargas, havia já décadas de convívio com Tolstói e Dostoiévski em livros e teses de medicina e direito, nos quais eles eram estrelas das teorias da psicopatologia e da cri-

\footnotetext{
90 A desconfiança de Barroso também pode ser verificada em outros dois artigos: no primeiro, ele discorda de uma lista de melhores contos feita por um russo, e oferece em contrapartida a sua própria, sem nenhum eslavo. No outro, retoma o velho tema das ambiguidades de Tolstói. Gustavo Barroso, "Os melhores contos do mundo", A manhã, n. 01313. Rio de Janeiro, 18 nov. 1945; Gustavo Barroso, "As duas faces de Tolstoi", A manhã, n. 01818. Rio de Janeiro, 15 jul. 1947.

91 "O que era o regime maximalista na Hungria", O imparcial, 10 ago. 1919.

92 Gregorio Bessedovsky, "As infâmias da "diplomacia" comunista", O Jornal, 2 maio 1931.

93 A esse respeito, ver: J. H. de Sá Leitão, "Heróis de Dostoiewski", Jornal do Brasil, 20 out. 1936; A., "Quando eu for grande", A Federação, 15 dez. 1936; Benjamin Lima, "As confissões da Soviecia", Jornal do Brasil, 29 abr. 1938; "Os homens-pestes", Jornal do Brasil, 28 ago. 1937.

94 Bruno Gomide, op. cit., 2011. João, "Um episódio da Casa dos Mortos", A Federação, 25 jul. 1916. Dostoiévski é apresentado como o "maior gênio da Rússia", em função de sua sensibilidade penal.
} 
minalística. Esse foi um dos caminhos mais potentes de consagração da ficção russa no Brasil, e perpassava orientações políticas as mais diversas. Com frequência, a literatura russa era situada na chave da sensibilidade social, em acepções que precediam a Revolução Russa e que com esta ganhariam contornos suplementares. Uma mocinha fora raptada, desonrada e jurada de morte por um telegrafista do Ministério da Agricultura; ao tentar o suicídio, foi salva por um homem com quem passara a perambular pelas ruas de Santa Teresa, no Rio de Janeiro, de onde foram levados ao $13^{\circ}$ distrito policial. Ao se defrontar com essa cena, o delegado a descreveu como uma verdadeira "página de Górki" ${ }^{95}$ Os presídios brasileiros eram pardieiros infectos, necessitados de intervenção urgente. Para uma reflexão aprofundada sobre o assunto, estavam à disposição as obras de Dostoiévski, Kropótkin e Górki - esta era a opinião do tenente Albino Monteiro. ${ }^{96}$

Um investigador policial podia perfeitamente ser simpático a Tolstói e anticomunista ferrenho. Não só não havia necessariamente incompatibilidade entre a polícia, os agentes penais e a literatura russa, como esta última inclusive chegava a servir de guia empírico, manual de conduta, fonte de inspiração. Crime e castigo, em especial, era considerado um ótimo modelo para investigadores. Uma reportagem noticiava que um grupo de policiais argentinos passara pelo Rio de Janeiro e comentara aos colegas as modernas técnicas de perícia que haviam visto em Paris, onde não presenciaram uma vez sequer a polícia lançar mão de meios violentos para obter confissões (resta saber a reação dos policiais brasileiros a essa explanação). A polícia parisiense supostamente não alterava a sua conduta mesmo diante de crimes bárbaros. Bastava um "co-

\footnotetext{
95 "Parece uma página de Gorki, disse o delegado do 130", Correio da manhã, 19 fev. 1915.

96 Albino Monteiro, "Os nossos presídios", Jornal do Brasil, 16 nov. 1920. Nessa linhagem de policiais amigos da literatura russa, cabe uma menção ao prolífico e longevo escritor paranaense Valfrido Pilotto, delegado de polícia e autor de dezenas de obras, entre as quais uma sobre Tolstói, publicada nos anos sessenta (Tolstói e os caminhos da redenção). Seu primo, Erasmo Pilotto, trabalhou na imprensa e foi ligado ao movimento da Escola Nova no Paraná. Também foi admirador de Tolstói, como comprova esse artigo: Erasmo Pilotto, "Tolstoi", Joaquim, abr. 1946.
} 
missário inteligente" para capturar o bandido mais renitente. "Pode servir de modelo, para os profissionais de polícia, aquele comissário de Crime e castigo, conhecido livro de Dostoievski, que é uma das suas criações mais perfeitas e mais reais". ${ }^{97}$ Outra reportagem, sobre a visita de Adhemar de Barros, então interventor federal, a instituições prisionais e psiquiátricas no estado de São Paulo a descreveu com tinturas dostoievskianas, a propósito dos "horrores que em tais xadrezes se passavam". ${ }^{98}$ Muitos juristas e médicos criminalistas escreviam seus trabalhos de conclusão de curso com o auxílio da literatura russa, tomada como inspiração geral ou fonte primária. Um deles, do norte do Brasil, escreveu na juventude uma monografia sobre Dostoiévski, pelo que o escritor amazonense Benjamin Lima o congratulou. Se ele hoje era um juiz "moral e compassivo", isso se devia ao "contato em tenra idade com o russo". ${ }^{99}$ Ler os russos melhora as pessoas e as instituições: muitos textos foram escritos no Brasil da primeira metade do século vinte tendo essa premissa que tanto agradaria a Tolstói ou a Dostoiévski. ${ }^{100}$ No auge da ditadura varguista, é inquietante achar esse tipo de arrazoado sobre a desejável influência da literatura russa na melhoria concreta das condições de prisões para onde eram levadas pessoas que eram flagradas lendo literatura russa.

\footnotetext{
97 “Um modelo de investigação policial”, Jornal do Brasil, 1 nov. 1928.

98 "A assistência aos doentes mentais", Correio paulistano, 4 nov. 1938.

99 Benjamin Lima, “Um juiz de menores”, Jornal do Brasil, 7 jun. 1941.

100 "Reforma penal e penitenciária", Correio paulistano, 11 jun. 1941.
} 